Feature Article

\title{
21ST CENTURY SOCIALIST-FEMINISM
}

\section{JOHANNA BRENNER}

Portland State University

\section{Biographical Note}

Johanna Brenner is a socialist-feminist scholar and community/labor activist in Portland, OR where she currently organizes with Bus Riders Unite and the Northwest Labor Notes network. She is the author of Women and the Politics of Class and has written on feminist theory and politics for left publications such as Against the Current, Socialist Register, and Monthly Review as well as feminist journals. She is Professor Emerita at Portland State University where she directed the Women's Studies Programme for many years. She was the keynote speaker at the Society for Socialist Studies annual meeting at the University of Victoria, Canada in June 2103.

Contact information: brennerj@pdx.edu

\begin{abstract}
This article considers feminist politics in the context of global capitalist restructuring. The incorporation of liberal feminist ideas into the contemporary neo-liberal capitalist order of the global north is analyzed through an intersectional lens and in relation to the successful employers' assault on the working class which set the stage for the defeat of the radical equality demands of feminists, anti-racist activists, indigenous peoples and others which had flourished in the 1960s and 1970s. In the 21 st century, it is argued, in response to structural adjustment policies enforced by neo-liberal capitalism in both the global north and global south, women of the working classes have entered the political stage through a broad array of movements. The article explores how these movements are creatively developing socialist feminist politics. The article concludes that this socialist-feminist politics has much to offer the left as it gropes toward new organizational forms and organizing strategies.
\end{abstract}

\section{Keywords}

austerity, gender violence, intersectionality, neo-liberalism, transnational feminism, socialist-feminism, women's movement

\section{Acknowledgement}

Many thanks to Meg Luxton for her comments and suggestions. 


\section{1th Century Socialist-Feminism}

Looking back to the heady days of feminism's "second wave" 1 in the United States, it is distressing to acknowledge that the movement's revolutionary moment is a dim memory, while key aspects of liberal feminism have been incorporated into the ruling class agenda. Liberal feminist ideas have been mobilized to support a range of neo-liberal initiatives including austerity, imperial war, and structural adjustment. For example:

\section{Austerity}

Welfare reform essentially ended income support for solo mothers even of very young children and forced them into low-waged work. This shift was justified as an intervention providing women with jobs and therefore "economic independence."

\section{Imperial War}

The US government used the liberation of women as cover for the invasion of Afghanistan and ties the "war on terrorism" (e.g. in Pakistan) to freeing women from patriarchal control.

\section{Structural Adjustment}

World Bank micro-credit loan programs targeted to women are a neo-liberal substitute for government-subsidized anti-poverty programs. Micro-credit is touted as a route to women's empowerment and economic independence through entrepreneurship.

Surely it is important to understand how it came to pass that feminist ideas have been so firmly incorporated into the neo-liberal order. But some recent explanations offered by feminist scholars point us in an unfortunate direction (Eisenstein, 2009; Fraser, 2009). ${ }^{2} \quad$ These writers argue that second wave feminism, with its overemphasis on legal rights and paid work as a route to equality, unwittingly paved the way for neo-liberalism. It is comforting to think that feminism had this level of control over the outcome of our struggles. For, were it true, we could now correct our mistakes, change our ideas, and regain our revolutionary footing. I want to make a different argument. Liberal feminism's partial incorporation into the neo-liberal economic, political, cultural and social order is better explained by the emergence of a new

1 I use this term as a shorthand for the feminist organizing that emerged in the mid-1960's and reached its height in terms of reach, multiplicity of points of view and radicalization in the 1970's. I specify my meaning of the term in order to acknowledge the many very good critiques of the "wave" metaphor, its historical inaccuracies, and its exclusions. (See, e.g., Hewitt, 2010)

2 For a trenchant response to Fraser, see Sangster and Luxton (2013). I am grateful for their thorough critique of Fraser's analysis. Their article frees me up to focus here on my own analysis which is quite compatible with their perspective on feminist history. For an appreciative but critical review of Eisenstein's book, see Johanna Brenner, (2010). 
regime of capital accumulation that has fundamentally restructured economies in both the global north and the global south. In the global north, this new regime was ushered in by the employers' assault on the working class, on the welfare state, and on the historic institutions of working class defense - unions and social democratic parties. This assault set the political context for the successful backlash against the radical equality demands of feminists, anti-racist activists, indigenous peoples and others and the rise of neo-liberalism (Brenner, 2000, Ch 7).

While the new regime of capitalist accumulation in the first instance extinguished the radical promise of the "second wave," it is also creating the material basis for the renewal and spread of socialist-feminist movements led by women of the working classes -- and I mean working classes in the broadest sense -- whether they are women employed in the formal economy, the informal economy, in the country-side or doing unwaged labor. The political discourses and movement building through which socialist feminism is being enacted in the 21 st century are a resource for the left that everywhere is struggling to find its feet. People have a sense that the old forms of left politics will not do. In this search for alternatives, socialist-feminist strategies have much to offer.

\section{$20^{\text {th }}$ Century Feminism}

To understand what happened to feminism, we need a class analysis. I mean class in two senses: 1) class as capitalist relations of production, the dynamics of the capitalist economy - its logic so to speak; 2) class as one of many important axes of domination - of unequal distributions of power and privilege - around which capitalist societies are structured.

As a Marxist feminist, when I think about capitalist relations of production, I am also drawing on the concept of social reproduction. All societies have to organize the labor involved in maintaining and renewing the population - Marxist feminists term this social reproduction and we focus on this theoretical concept because the work of social reproduction is fundamental to human survival. Social reproduction includes caring labor but also includes how sexuality is organized -- not only because of biological reproduction but because intimacy and desire are mobilized in and through institutions that organize social reproduction-in capitalism, for example, the privatized, nuclear family household.

Thinking about class in the second sense, I draw on the concept of intersectionality. In feminist theory intersectionality has emerged as an analytic strategy to address the interrelation of multiple, cross-cutting institutionalized power relations. ${ }^{3}$ Here class is just one axis of power

3 This concept first emerged in the 1970's from the practice and theorizing of revolutionary Black feminists-see,for example, the Combahee River Collective statement-and was further developed by women of color feminist theorists including Audre Lorde, Barbara Smith, Angela Davis, Cherie Moraga, Andrea Smith, Patricia Hill Collins and Kimberle Crenshaw. Although "intersectionality" is, unfortunately, more often invoked than actually practiced, fully incorporating all of the axes of power/privilege in our political analysis and action remains feminisms' central task. 
among others including race, gender, sexuality, citizenship status, ability, and so forth. Most intersectional analysis draws on the concept of social location, a "place" defined by these intersecting axes of domination, and asks how a social location shapes experience and identity (Collins, 2000, Dorothy Smith 2005). I use the concept of survival projects to express the connection between intersectional social locations and social action, including but not limited to political activism. I like the idea of survival projects because a)survival, in the broadest Marxist sense, asserts that there is a materiality to social action, b) project implies intentionality and rationality but also projects are open-ended-and that makes room for praxis-the possibilities for self-change that inheres in collective action; and c) projects indicate motivation and drive-and allow us to think about the ways in which social action, including collective action, mobilizes emotions and affect (Brenner, 1998). In conceptualizing the relationship between social location and social action, I also draw on the Black feminist thought of Patricia Hill Collins. In analyzing how Black women negotiate their specific social locations she distinguishes between resistance within the constraints of these locations - within the rules of the game, so to speak -- and resistance that aims to change those rules (Collins, 2000, Ch. 9). When I talk about class as a relation of power and privilege similar to gender or race/ethnicity I'm going to use the concept of the professional/managerial class - a contradictory class location that shares, at its upper end, conditions of life close to those who own and control the means of production and, at its lower end, conditions of life much closer to those of the working-class (and I acknowledge the fuzziness of this boundary).

So, back to the story: what, after all, did happen to 20th century feminism in the US?

The dominant feminist political discourse in the "second wave" was not classic liberal feminism -- that is, a feminism that wanted to clear away any impediments to women's exercise of their individual rights - but rather what I would call social-welfare feminism. (Outside the US where there were actual left parties and where socialist political discourses were more available to feminist activists, this politics could be called social-democratic feminism). Social welfare feminists share liberal feminism's commitment to individual rights and equal opportunity, but go much further. They look to an expansive and activist state to address the problems of working women, to ease the burden of the double day, to improve women's and especially mothers' position on the labor market, to provide public services that socialize the labor of care and to expand social responsibility for care (e.g., through paid parenting leave, stipends for women caring for disabled family members).

Women in the affluent end of the professional/managerial class are the social base of classic liberal feminism. Social welfare feminist politics finds its social base predominantly in the lower reaches of the professional managerial class and especially women employed in education, social services, and health. Professional/managerial women of color are more likely to be employed in these industries than in the private sector. Women trade-union activists also played a significant part in leading and organizing social-welfare feminism.

We can generously characterize as ambivalent the relationships between working-class women/poor women and the middle-class professional women whose jobs it is to uplift and 
regulate those who come to be defined as problematic - the poor, the unhealthy, the culturally unfit, the sexually deviant, the ill-educated. These class tensions bleed into feminist politics, as middle-class feminist advocates claim to represent working-class women. The way these class tensions get expressed is shaped considerably by other dimensions of class locations such as race/ethnicity, sexuality, nationality, ability (Richie, 2000; Mink, 1995). The politics of middle-class feminists also shift depending on the levels of militancy, self-organization, and political strength of women in the working classes.

A compelling instance of this dynamic can be seen in the first half of the 1970s. In the political context of the Black struggle for economic justice, driven by the Black working class, and the welfare rights movement that was the civil rights movement's working-class feminist leading edge, social welfare feminists took up a visionary and broad-based program of expanding state support for caring labor. For example, in 1971, a coalition of feminist and civil rights organizations won the Comprehensive Childcare Act (CCA) that would have established day care as a federally funded developmental service available to every child who needed it. Although no doubt feminists saw this legislation to be crucial to mothers' employment, they did not limit the benefit only to mothers working for pay. The program included provisions for medical, nutritional, and educational services for children from infancy to fourteen years of age. Services were to be on a sliding fee scale (Rosen, 2000, p. 79, 90-91, 292-294). President Nixon vetoed the bill, but organizing around it continued throughout the 1970's.

In this historical moment, the politics through which social-welfare feminism fought for socializing the labor of care drew on ideas of the National Welfare Rights Organization, which reflected the social location of its core activists - poor black women. What is most interesting about the NWRO's political discourses is their capacity to creatively combine claims that philosophers, lawyers, and academics tend to see as competing. I have in mind here the distinction between "needs talk" and "rights talk" (Fraser, 1989; Hobson et. al., 2002). Maternalist political discourses are quintessential examples of "needs talk." Here, advocates make claims based on children's needs and mothers' unique capacity to fulfill those needs. On the other hand, the demand for gender-blind employment practices or equal access to professional schooling is quintessential "rights talk," demanding individual rights for women that are already granted to men. The emerging Black feminism of the NWRO activists rejected this "either/or" counter-position of different strategies for claims-making. Johnnie Tillmon, the charismatic leader of the welfare rights movement, published a ground-breaking article in $M s$. magazine (1972) where she compared being on welfare to marriage - women on welfare, she said, were "married to the state" and, like wives, were economically dependent and disempowered. The condition for receiving assistance was to allow government institutions to control your sexuality, your household and your parenting. The NWRO argued for a program of guaranteed, that is unconditional, minimum income for single mothers. Poor women should have choices about how they parented and they, themselves, were the only appropriate authorities to establish their children's needs. They should receive economic support and social services whether they were stay home mothers or working parents. The welfare rights activists 
critiqued the employment programs that were part of the federally-funded war on poverty where single mothers were channeled into training for traditionally female, low paid, pink color jobs. Finally, they linked their demand that motherhood be recognized as valuable work to women's economic autonomy and their right to self-determination (West, pp. 89-93, p. 247, Nadasen, 2012, pp. 44-51).

This "both/and" politics was reflected also in women of color's challenge to the pro-choice movement. Where the radical and liberal wings of the feminist movement focused on women's rights to bodily autonomy - and the right to refuse motherhood - women of color were facing a very different assault - forced sterilization of poor women in public hospitals where they gave birth (Davis, 1983, Ch 12, Nelson, 2003). Further, the welfare rights movement was organizing poor women and especially black women, to challenge the denigration of their motherhood and the stigmatization of their sexuality. Taking up the ideas of working-class women of color activists, socialist-feminists in the anti-capitalist left articulated a politics of reproductive rights that reached beyond the language of choice ${ }^{4}$ (Gordon, 2012). Reproductive rights included the right to be mothers, to raise our children in dignity and health, in safe neighborhoods, with adequate income and shelter. Reproductive rights is a program of non-reformist reform-- some of these demands can be fought for and won under capitalism--for example, to outlaw racist sterilization abuse or discrimination against lesbian mothers-but the full program of reproductive justice is incompatible with capitalism. In this respect, reproductive rights political discourses bridge feminism to anti-capitalist politics. In the U.S. today, Sister Song, a coalition of forty women of color groups animated by a program of what they term reproductive justice, exemplifies this politics and has had some success in pushing the mainstream pro-choice organizations to broaden their political agenda. (http://www.sistersong.net/)

At its height, second-wave feminism argued for socializing the labor of care. Shifting care from an individual to a social responsibility required then and requires today a redistribution of wealth from capital to labor. Social responsibility for care depends on the expansion of public goods which in turn depends on taxing wealth or profits. ${ }^{5}$ Compensating workers for time spent in caregiving (e.g., paid parenting leave), expands paid compensation at the expense of profits. In addition, requiring (either by regulation or by contract) that workplaces accommodate and subsidize employees' caregiving outside of work interferes with employers' control over the workplace and tends to be resisted in the private sector where jobs continue to be organized as if workers had very little responsibility for care. In other words, to socialize the labor of care requires confronting capitalist class power. And it was here that 20th c. social welfare feminism foundered. To confront capitalist class power required a broad,

\footnotetext{
4 On the similar development of a reproductive rights politics in Canada, see Egan and Gardiner, (1999).

5 Capitalist welfare states have expanded primarily through taxing salaries and wages rather than wealth and profits; however, there are distinct economic and political limits to this strategy for funding public goods.
} 
militant, disruptive social movement - an anti-capitalist front linking feminism, anti-racism, gay rights, and immigrant rights to trade unions and workers' struggles. What existed instead were bureaucratic, sclerotic, sectoralist trade unions that had neither the interest in nor capacity for building movements of any kind.

Almost at the very moment of social-welfare feminisms greatest strength, in the 1970's, the tsunami of capitalist restructuring arrived, opening up a new era of assault on a working class that had no means of defending itself. As people scrambled to survive in this new world order, as collective capacities and solidarities moved out of reach, as competition and insecurity ratcheted up, as individualistic survival projects became the order of the day, the door was opened for neo-liberal political ideas to gain hegemony. Caught between a demobilized working-class and a Democratic party overtaken by neo-liberalism, middle-class social welfare feminists began to accommodate to the existing political realities. For example, leaving behind the "both/and" politics of the NWRO, middle-class advocates moved away from the maternalist discourses - e.g. "young children need to be with their mothers" - that, however problematic, had been part of their defense of income support to single mothers. And they moved toward neo-liberal discourses of "self-sufficiency" in the face of a fierce bi-partisan critique of the welfare system for encouraging "dependency." They embraced the idea of "self-sufficiency" through paid work, even though it was quite obvious that the low-paid precarious jobs open to so many single mothers would never pay a living wage, that the childcare stipends provided (to the poorest women) were inadequate for quality childcare, and that after-school programs for older children were unaffordable. ${ }^{6}$ In other words, second-wave social welfare feminism was not so much coopted as it was politically marginalized. And in the context of that defeat, not surprisingly, liberal feminist politics not only moved center stage but became incorporated into an increasingly hegemonic neo-liberal capitalist regime.

Ironically, as middle-class advocates moved rightward, working-class feminists, especially in unions with large or majority women members, were making substantial gains. They increased women's representation in leadership, pushed their unions to support political mobilizations defending legalized abortion (CLUW's "pro-union, pro-choice" campaign) and opposing discrimination against LGBT people, and placed demands like comparable worth and paid parental leave onto the bargaining agenda. However, these latter gains rang hollow, as unions lost ground so swiftly, including at the bargaining table. ${ }^{7}$

Feminism and other movements against oppression will be cross-class movements and therefore pose the question, "who will have hegemony within those movements?" Whose worldviews will determine what the movement demands, how those demands are articulated and justified, and how the movement itself is organized? In the ordinary course of events, the

\footnotetext{
6 For a more nuanced account than is possible here, see Brenner, (2000), Chs. 5 \& 6.

7 On working-class women's feminism see, for the US, Dorothy Sue Cobble (2004). For Canada, Brisken and Yanz (1983) and Luxton (2001).
} 
answer to these questions is the middle-class. ${ }^{8} \quad$ Yet, as in the moment of the second wave's greatest radicalization, when working-class people walk onto the political stage, the power relations within social movements can shift.

\section{Socialist-Feminism in the 21 st Century}

Looking back, we can see how the fate of socialist-feminism is closely tied to the fate of the broader institutions of working-class struggle. Socialist-feminists have always engaged in a two-sided effort: to bring an anti-racist, class-based feminist perspective into social movements and left political parties and a socialist perspective into feminist politics and women's movements. Social-welfare feminism, social-democratic feminism, revolutionary socialist feminism, revolutionary women of color feminism, indigenous feminism, are some of the different currents within socialist-feminist politics. We can think of socialist feminism very broadly-- to include all feminists (whether they would identify with the label or not) who see class as central but would not reduce relations of power and privilege organized around particular identities (e.g., gender, sexuality, race/ethnicity, nationality) to class oppression. Revolutionary socialist feminism is distinguished from social welfare or social-democratic feminism in that, whether implicitly or explicitly, revolutionary socialist feminists are unwilling to allow capitalism to set the horizon for what can be envisioned or struggled for.

Socialist-feminists start where most feminists begin: that the emancipation of women must come from women ourselves, but cannot be achieved by ourselves. From this starting point, socialist-feminists are especially interested in building inclusive movements organized by and for working class, indigenous, and rural women. Women's self-organization can be parochial or coalitional - that is, it can either reproduce existing social divisions among women or reach beyond them. The political imaginary through which socialist-feminists organize aims to develop activism and leadership, education and awareness, demands and discourses, and an everyday politics that recognizes and works to overcome these deep divisions. In this process, like the women of the NWRO, socialist feminists look to developing a "both/and" politics that bridges what might be won in the here and now to a longer term project of social transformation. In the 21st century, women have entered the global political stage in an astonishing array of movements. Sparked by the capitalist war on the working class, the enclosures sweeping peasants and farmers off the land or devastating their livelihoods upon it, and the consequent crisis and intensification in patriarchal relations, these movements are creatively developing socialist feminist politics. And this politics has much to offer the left as it gropes toward new organizational forms and organizing strategies.

The 21st century has seen an expansion and deepening of transnational feminist networks. There are, of course, class tensions within these networks and some networks deal with these tensions better than others (Alvarez 2000, Moghadam 2005). Still, the networks are

8 For a case study, see Valocchi (1999). 
crucial resources for socialist-feminist organizing, for it is through them that feminist discourses circulate globally, are incorporated locally and often creatively re-shaped in the process (Sameh, 2010).

In the global south, as women find themselves displaced, employed in precarious work, heading households, struggling to survive in informal settlements and urban slums, they are not only crucial participants in movements for 21 st c. socialism, they are also building grass-roots organizing projects that challenge patriarchal forms of organizing, leadership, and movement demands. In the global north, these grass-roots projects have engaged new modes of worker organizing (such as the Domestic Workers movement) that rely on mobilizing members and building community alliances. While never perfect, of course, these different socialist-feminist projects, in north and south, in community and workplace, at their best offer new discourses of gender equality, new modes of organizing, and visions of participatory democracy.

I think we all recognize that a democratic spirit is in the air - exemplified in Occupy, Tahrir square and the Indignados. These movements echoed the popular assemblies and other democratic experiments such as participatory budgeting that have been so central to the project of building " 21 st century socialism."

Beyond these moments of upsurge, women of the working classes have been carrying forward grass-roots projects that incorporate and draw from the participatory democratic ethos that will be central to reconfiguring the left. Women of the working classes are easily shut out of formal, hierarchical, bureaucratic organizations and, because they are so central to local movements, they have had the most to gain from new forms of citizenship that encourage and support political participation from the ground up (for example, Fernandes, 2007). Their organizing projects aim to build alternatives to "masculinist" and hierarchical styles of work which are barriers to women's self-development and leadership. Yet, they are also intent on organizing in communities and workplaces to win reforms, including reforms in law and government policies. Thus, activists are forced to think through how to meld the "horizontalism" inspired by the Zapatistas and other autonomous left currents with activist engagement with the state.

In what follows I offer two examples of organizing projects, The Coalition for Justice in the Maquiladoras (CJM) and Via Campesina, that illustrate these different aspects of socialist-feminist strategies and their potential contribution to organizing anti-capitalist struggle. ${ }^{9}$

Formed in 1989 during the NAFTA debates, CJM is a multi-sectoral, international coalition that supports Mexican factory workers. CJM's coordinator, Marta Ojeda, began as a maquiladora worker, became an organizer, and eventually helped to found CJM.

9 For further discussion of these and other examples of socialist-feminist organizing, see Brenner and Holmstrom (2013). 


\section{Building Self-Organization}

CJM teaches workers to do their own research on the companies, mapping the process of production, identifying the costs of inputs, comparing that to the prices of the products sold, identifying health and safety conditions that violate international labor law. Working together builds trust and cohesion. Additionally, by developing workers' knowledge and analytic skills, CJM undermines the mystique of expertise that is so crucial to managerial authority and encourages confidence in a democratic socialist vision of society.

\section{Bridging Racial/Ethnic Divides}

One of CJM's areas of organizing on northern Mexico's border is Nuevo Laredo, Tamaulipas, a hub for maquiladoras. Between 2001 and 2007, CJM organized several meetings that brought together maquiladora workers and campesinos and indigenous community members from Chiapas (Hennessy, 2010 \& 2013). In addition to creating a space for thinking critically about gender relations, these meetings bridged historic racial divisions between the indigenous people from Mexico's south and maquiladora workers in the north. They enabled communities to learn from each other's long history of organizing.

\section{Connecting Workplace and Community}

In 2004, workers and their families sought to settle on formerly ejido land where they could live without paying rent and grow some of their own food. After invading the land, residents were evicted by order of the mayor of Nuevo Laredo; but they returned again in 2005 to claim their land. Women took the lead in organizing against the eviction and in returning to establish their community. Originally the colonia residents organized for recognition and services from the city government, but after enduring several years of the government's violence and neglect, and following several exchanges with activists from the Zapatista communities in Chiapas, they decided to channel their energies into sustaining themselves. Women continue to play leadership roles there and residents are pursuing sustainable economic projects such as taking over a nearby water source and installing faucets on several streets, building a small clinic, solar ovens, and a wind generator, and establishing community gardens of fruit trees, vegetables, and medicinal herbs.

\section{Contesting Gender Oppression}

CJM provides childcare for all their meetings and functions and encourages the small but significant "gender adjustments" that emerge in women's lives when they become politically active. CJM's Worker Empowerment Program, provides an opportunity for women to develop 
analyses of gender relations in their homes, organizations, and communities. According to Ojeda,

The women organizers involved in the CJM Empowerment Program make connections among all forms of violence. They learn that the root of the problem is not just a patriarchal system but also a capitalist system that behind the scenes generates violence against women, including the latest violence perpetrated by organized crime, which is also a consequence of the neoliberal capitalist regime. Women of the colonia Blanca Navidad in Nuevo Laredo, women from the maquilas, indigenous women and campesinas from Chiapas who have been involved in the encuentros relate violence to the lack of land rights, lack of access to decent housing and jobs, to health care, and education (Brenner, 2012).

Violence Against Women has also been taken up by rural women organizers in La Via Campesina, an international coalition of peasants, farmers, farm workers and indigenous agrarian communities from a wide diversity of locations and cultures. Women activists in Via have been organizing to reshape gender relations within their organizations and in their communities. At its founding, in 1992, Via reflected the patriarchal norms and political outlook of its member organizations - for example, all of the regional coordinators elected at the first international conference were men. ${ }^{10}$ The formation of a Women's Commission in 1996 created the space for women within Via Campesina to organize to challenge patriarchal practices and policies. Although special organizational bodies for dealing with women's issues can be instruments for cooptation and marginalization, this has not been the case in Via Campesina. Annette Demarais argues that this is partly because of the (relatively) democratic functioning of the Via.

The Women's Commission, and the separate international conferences for women activists it organized, have had a significant impact on the representation of women in Via and in its member organizations. In October 2008, La Via Campesina's 3rd International Assembly of Women approved the launch of a campaign targeting all forms of violence faced by women in society (interpersonal as well as structural). In linking state violence directed at their communities to violence against women perpetrated in their communities, the women of Via Campesina followed a path taken by Indigenous women and women of color organizing against gender violence in North America. Mainstream feminist anti-violence organizations have essentially dropped any critique of the repressive arm of the state and regard discussion of the link between men's violence and conditions of oppression and exploitation as "letting men off the hook." Women of color organizations have insisted that gender violence in their communities cannot be dealt with in separation from the violation of their communities (Incite! 2006). Sacred Circle, a South Dakota based American Indian resource center for domestic and

10 The following account is based on Desmarais (2007) and Vivas (2012), 
sexual violence, argues that Indigenous sovereignty cannot be achieved without the well-being of Native Women (Haaken, 2012, 37-40). From their particular social location, Indigenous women activists are here developing a politics that rejects the counter-position of collective to individual rights by demonstrating that both winning collective rights (sovereignty) and building a community based on those rights, depends on the full participation and equality of women (recognition of their individual bodily rights) within a community of struggle (Smith, 2007).

In June 2013, following the lead taken by the Women's Assembly, held just prior to their 6th International Conference, Via Campesina voted to include, for the first time, opposition to homophobia as part of the organization's program of work. The Call voted on by the VI Conference of La Via Campesina states:

We demand respect for all women' rights. In rejecting capitalism, patriarchy, zenophobia, homophobia and discrimination based on race and ethnicity, we reaffirm our commitment to the total equality of women and men. This demands the end to all forms of violence against women, domestic, social and institutional in both rural and urban areas. Our Campaign against Violence towards Women is at the heart of our struggles (Via Campesina, 2013).

This is especially interesting because sexual self-determination and abortion rights have often been "off the table" in movements engaging women of the working-classes and, more generally, there have been significant tensions (which map onto differences of race/nationality/ethnicity and class) between activists organizing around women's practical gender interests (based in women's caring roles in family and community) and activists organizing around demands that emerge from women's strategic gender interests (based in women's search for bodily and sexual self-determination) (Molyneux, 1985). ${ }^{11} \quad$ In the 21 st century, socialist-feminist ideas have gained much greater purchase as women in popular movements, whether urban or rural, have self-organized to challenge patriarchal norms. It seems that in the Via Campesina, the tension between practical gender interests and strategic gender interests has been overcome, at least in part, through the organization of women within Via and their productive collaboration with the World March of Women and other socialist-feminist transnational organizations.

Via's recognition of homophobia reflects the global mainstreaming of LGBT rights which has proceeded with an almost unprecedented rapidity over the last few years. Yet, it is important to note that, in contrast to the liberal politics of marriage rights now sweeping the US, in Via Campesina, the struggle against homophobia is inserted into an inclusive collective vision of transformation that is also anti-racist and anti-capitalist.

Turning now to the global north, I want to bring into focus the politics of caring labor

11 As a contemporary example of this conflict, Susan Spronk describes the disconnect between Bolivian feminists using a language of individual rights and indigenous and peasant women activists who are more concerned about malnutrition and death in childbirth (Spronk, 2013). 
and how a socialist-feminist perspective might contribute to organizing against austerity. Although the strength and reach of public services varies widely across countries, everywhere the trend is toward the privatization and informalization of caring for young children, the elderly, the disabled and the ill. This is the prominent face of neo-liberal structural adjustment in the global north. It has created a demand for immigrant labor and is responsible for shifting the gender of migrants from the south to the north from predominantly male to predominantly female (Gündüzf, 2013). Women workers in the care sector span a wide range in terms of class - from trained early education teachers and managers of day care centers to the childcare workers, teachers' aides, house cleaners, nannies, home care workers, nursing home attendants, and others whose skills are unrecognized and low-paid. Differences of citizenship status and racial/ethnic identity are mapped onto class differences here as well. If we expand our view of caring labor to include hospitals and public schools, we see that women workers and their unions are increasingly under the sign of the "welfare queen" - entitled drains on the budget and lazy as well - in other words, barriers to improving public services.

Women trade unionists, especially teachers and nurses, have pioneered to counter this assault by organizing not only themselves but also the people who depend on their services. As militant teachers have claimed, "our working conditions are our students' learning conditions." (Bradbury et. al. 2014) The California nurses' association organized a broad coalition to pass legislation mandating nurse-patient ratios in hospitals. (National Nurses United, 2013) Perhaps, most unexpected, Domestic Workers United, an organization that began with nannies and housecleaners organizing in New York City, won not only a domestic workers' "bill of rights" for the city and then in the New York state legislature, but encouraged the expansion and establishment of other domestic worker organizing projects. This national movement recently won a ruling from the Federal Government that, for the first time, domestic workers would be covered by federal laws regulating hours of work, health and safety, overtime pay, and the right to time off (Dean, 2013). Across the differences among nurses, teachers, and domestic workers, these projects share two central strategies: 1) organizing in and beyond the workplace and 2) raising awareness of and support for the dignity and importance of caring work. They enact social solidarity, remind us of our inter-dependence, and defend social responsibility for care. In these ways, they represent a fundamental challenge to neo-liberal ideals of entrepreneurship, individualism, and "self-sufficiency."

One of the most compelling neo-liberal political discourses is the demand that government be made more accountable by contracting out government services to private and non-profit organizations that are supposedly more flexible and responsive to those who depend on them. We can effectively counter this neo-liberal agenda by building on the experiments in democratizing government that have been won through popular and trade union struggles. These creative initiatives offer alternatives to bureaucracy far more compelling than the phony involvement and superficial accountability promised by privatization. Women are much more present than men as paid care workers and as recipients of caring services (often on behalf of children and adult kin); a movement to democratize care will be a women's movement. As 
ever, there will be class tensions and differences especially of race/ethnicity and citizenship to be addressed. Nonetheless, democratizing care is a fruitful avenue for developing socialist-feminist politics and expanding how the left understands the fight against austerity.

Attempts to democratize the state through new institutions of participatory democracy have been at the heart of the movement toward 21st c. socialism in Latin America. In the global north, experiments to "open-up" government have been much less spectacular but are nonetheless inspiring. They are far from perfect and there is still much to learn. Still, programs to democratize the state creatively break from the modes of organizing and thinking about government that have dominated union and left strategies, leaving us stuck in a dead-end debate about whether or not to work to reform the state or create autonomous pre-figurative alternatives to the state.

In Reclaim the State, Wainwright describes the successes and failures of several attempts to democratize government. One, in particular, in Newcastle England, interests me, because it is about a public sector union competing with a private contractor when the local council decided to "outsource" an entire department. The union proposed a complete reorganization of the department including breaking the bureaucratic hierarchy, engaging workers in every key decision about processes and policies, sharing knowledge and expertise among workers, and providing retraining for individuals whose skills were made redundant. This was not the "teaming" so beloved by corporate managers but a real democratization through which the department operated more like a worker cooperative than a traditional government bureau. And rather than going around the union, the reorganization brought a level of union involvement at the worksite that previously had not existed (Wainwright, 2009, Chapter 8).

Another avenue for organizing to democratize and socialize caring work is the social cooperative. ${ }^{12}$ Social cooperatives are workers' cooperatives recognized and funded by the state and required to include service recipients in their governance. While not in themselves radical, social cooperatives are a field for struggle that challenges neo-liberal ideals and opens up a space for socialist-feminist politics. The neo-liberal identification of self-determination with "consumer choice" is both ideological and real. Consumer choice has power because it reflects the actual relationships between institutions that provide public services (whether non-profits or government programs) and the people who need them. While we can talk abstractly about public goods as those things we own in common, for the most part we experience ourselves in relation to public services as consumers. As users experience them, public goods delivered through bureaucratic, hierarchical, and inaccessible organizations are much closer to commodities than to a commons.

Social cooperatives, combining worker ownership with a mandate to include users of services in decision-making, create social relationships that have the potential to constitute publicly funded care services that are more like a "commons" than like consumer goods. On the other hand, they may also be used to facilitate a neoliberal agenda that undercuts public workers

\footnotetext{
12 For elaboration on the following argument, Brenner (2009).
} 
and their unions. A social movement unionism strategy that allies service users and public workers could contend for shared governance of schools, childcare-centers, home-care programs and many other institutions that are at the core of socializing the labor of care.

\section{Conclusion}

Socialist-feminist politics offers a unique strategic perspective for organizing in the 21st century. Socialist-feminists' commitment to self-organization supports organizational structures that are non-hierarchical and democratic and therefore more inclusive (Duggan, 2013). Attention to intersectionality as a guide to both program and political discourse - the demands that movements make and the language we use to support those demands - opens a ground on which deep social divisions might be overcome rather than reproduced. Understanding the ways that workplaces, households, and communities are inter-related leads to more effective modes of organizing and more possibilities for coalition politics, making connections between what are often seen as very different and separate issues/struggles. Socialist-feminist visions of leadership and of leadership development promote activists' capacities for engagement in democratic decision-making and collectivity. The recognition that affect, emotions, sexuality are always present, shaping social relations, encourages activists' self-reflection, empathy, and respect for different ways of being in the world.

In the 21 st century, as women of the working classes enter onto the political stage, they are creatively renewing socialist-feminist politics. If we are to build 21 st c. socialism, then it is time to pay attention to $21 \mathrm{st}$ c. socialist-feminism, moving its theory and practice from the margins to the center of the revolutionary left.

\section{Bibliography}

Alvarez, Sonia E., 2000, "Translating the Global: Effects of Transnational Organizing on Local Feminist Discourses and Practices in Latin America," Meridians: feminism, race, transnationalism, vol. 1, no. 1 (Autumn).

Bradbury, Alexandra et. al., 2014, How To Jump-Start Your Union: Lessons from the Chicago Teachers (Detroit: Labor Education and Research Project).

Brenner, Johanna, 1998, “On Gender and Class In US Labor History,” Monthly Review, vol. 50, n. 6. (November).

Brenner, Johanna, 2000, Women and the Politics of Class (New York: Monthly Review Press). 
Brenner, Johanna, 2009, “Democratizing Care," in Gender Equality: Transforming Family Divisions of Labor. Janet C. Gornick and Marcia K. Meyers (New York: Verso).

Brenner Johanna, 2010, “Free Market Feminism,” Monthly Review 62, Issue 07 (December).

Brenner, Johanna, 2012, "Interview with Martha Ojeda," (April 4).

Brenner, Johanna and Holmstrom, Nancy, 2013, "Socialist-Feminist Strategy Today," Socialist Register, 49.

Briskin, Linda and Yanz, Lynda, eds., 1983, Union Sisters: Women in the Labour Movement (Toronto: the Women's Press).

Cobble, Dorothy Sue, 2004, The Other Women's Movement: Workplace Justice and Social Rights in Modern America, (Princeton, N.J., Princeton University Press).

Collins, Patricia Hill, 2000, Black Feminist Thought, 2nd Edition (New York: Routledge).

Davis, Angela, 1983, Women, Race, and Class (New York: Vintage Books).

Dean, Amy, 2013, How Domestic Workers Won Their Rights: Five Big Lessons, Yes! Magazine, (October).

Desmarais, Annette Aurélie, 2007, La Via Campesina: Globalization and the Power of Peasants (London: Pluto Press).

Duggan, Penelope, 2013, “The feminist challenge to traditional political organizations," International Viewpoint, (November) http://www.internationalviewpoint.org/spip.php?article3186.

Egan, Carolyn and Gardner, Linda, 1999, "Racism, Women's Health, and Reproductive Freedom," in Scratching the Surface: Canadian Anti-racist, Feminist Thought, eds. Dua, Enakshi and Robertson, Angela (Toronto: Women's Press), 1999.

Eisenstein, Hester, 2009, Feminism Seduced: How Global Elites Use Women's Labor and Ideas to Exploit the World (CO: Paradigm Publishers).

Fernandes, Sujatha, 2007, "Barrio Women and Popular Politics in Chavez's Venezuela," Latin American Politics \& Society, Vol. 49 Issue 3, (Summer). 
Fraser, Nancy, 1989, “Talking about Needs: Interpretive Contests as Political Conflicts in Welfare-State Societies," Ethics, vol. 99, no. 2 (January).

Fraser, Nancy, 2009, “Feminism, Capitalism and the Cunning of History," New Left Review, (March-April).

Gordon, Linda, 2013, "Socialist Feminism in the Second Wave," New Labor Forum. 22, no. 3 (September).

Gündüzf, Zuhal Yeşilyurt, 2013, “The Feminization of Migration,” Monthly Review, vol. 15, no. 7 (December).

Haaken, Janice, 2012, Hard Knocks, Domestic Violence and the Psychology of Storytelling (NY: Routledge).

Hennessy, Rosemary, 2010, "Gender Adjustments in Forgotten Places: the North South Encuentros in Mexico," Works and Days, Special Issue on Invisible Battlegrounds: Feminist Resistance in the Global Age of War and Imperialism. 29, nos.1-2.

Hennessy, Rosemary, 2013, Fires on the Border: The Passionate Politics of Organizing on the Mexican Frontera and Elsewhere. (Minneapolis: University of Minnesota Press).

Hewitt, Nancy A., ed., 2010, No Permanent Waves: Recasting Histories of U.S. Feminism (New Brunswick, N.J.: Rutgers University Press).

Hobson, Barbara and Lister, Ruth, 2002, "Citizenship," in Contested Concepts in Gender and Social Politics, Barbara, Lewis, Jane, Siim, Birte (Northampton, MA: Edward Elgar) Incite! Women of Color Against Violence, 2006, Color of Violence, (Boston: South End Press).

Luxton, Meg, 2001, “Feminism as a Class Act: Working Class Feminism and the Women's Movement in Canada," Labour/le Travail 48, pp. 63-88.

Mink, Gwendolyn, 1995, The Wages of Motherhood: inequality in the welfare state, 1917-1942 (NY: Cornell U Press).

Moghadam, Valentine, 2005, Globalizing Women: Transnational Feminist Networks (Baltimore: Johns Hopkins University Press,). 
Molyneux, Maxine, 1985, "Mobilization without Emancipation? Women's Interests, the State, and Revolution in Nicaragua, Feminist Studies, Vol. 11, No. 2 (Summer).

Nadasen, Premilla, 2012, Rethinking the Welfare Rights Movement (New York: Routledge).

National Nurses United, "Nurses Answer the Call for Safe Patient Care," http://www.nationalnursesunited.org/issues/entry/ratios (accessed 12/28/13).

Nelson, Jennifer, 2003, Women of Color and the Reproductive Rights Movement,(New York: New York University Press).

Reagon, Bernice Johnson, 1983, 2000, “Coalition Politics: Turning the Century” in Home Girls: A Black Feminist Anthology, ed. Barbara Smith (New York: Kitchen Table Women of Color Press; New Brunswick, N.J.: Rutgers University Press).

Richie, Beth E., 2000, "A Black Feminist Reflection on the Antiviolence Movement," Signs: Journal of Women in Culture and Society, vol. 25, no. 4 (Summer).

Rosen, Ruth, 2000, The World Split Open (New York: Penguin).

Sameh, Catherine, 2010, "Discourses of Equality, Rights and Islam in the One Million Signatures Campaign in Iran,” International Feminist Journal of Politics, vol. 12, no. 4 (December).

Sangster, Joan and Luxton, Meg, 2013, "Feminism, Co-optation and the Problems of Amnesia," Socialist Register, no. 49.

Smith, Andrea , 2007, "Native American Feminism, " in Making Space for Indigenous Feminisms, ed., Joyce Green (Winnipeg: Fernwood Books).

Smith, Dorothy E., 2005, Institutional Ethnography: A Sociology for the People, (Oxford: AltaMira Press).

Spronk, Susan, 2013, “21st Century Socialism in Bolivia: the gender agenda," Socialist Register, no. 49.

Valocchi, Steve, 1999, “The Class-Inflected Nature of Gay Identity,” Social Problems, 46, no. 2 (May). 
Via Campesina, 2013.

[http://viacampesina.org/en/index.php/our-conferences-mainmenu-28/6-jakarta-2013/re solutions-and-declarations/1428-the-jakarta-call].

Vivas, Esther , 2012, "Without Women There is No Food Sovereignty," International Viewpoint, (February) http://www.internationalviewpoint.org/spip.php?article2473.

Wainwright, Hilary, 2009, Reclaim the State: Experiments in Popular Democracy, (London: Seagull Books).

West, Guida, 1981, The National Welfare Right Movement: The Social Protest of Poor Women (New York: Praeger. 